which may lead to serious postoperative bleeding are more commonly associated with certain cephalosporins having the $N$-methylthiotetrazole side chain ${ }^{22}$ but have been noted with others - such as cefuroxime-lacking this side chain..$^{23}$

Some investigators have suggested that the pharmacokinetic profile of an antibiotic is important if it is to be given only preoperatively and have advocated the use of antibiotics with prolonged elimination half lives-for example, ceftriaxone," which is not available in Britain. Our results imply that this is not necessary for operations lasting up to 90 minutes. The half lives of both cephalosporins used here are in the order of one to one and a half hours. Cefotaxime, however, undergoes desacetylation to a metabolite, desacetylcefotaxime, which has broad spectrum antibiotic activity and hence prolongs the duration of antibiotic activity of the parent drug. ${ }^{24}$ Nevertheless, for operations which extend beyond 90 minutes our results suggest that a peroperative "topping up" dose may be beneficial (though only 107 of $907(11 \cdot 8 \%)$ operations in this study were of greater than two hours' duration). It is evident that prophylactic postoperative doses of cefuroxime plus metronidazole confer no additional benefit over a single preoperative dose of cefotaxime plus metronidazole.

Interim results of this study were presented as posters at the 28th interscience conference on antimicrobial agents and chemotherapy held in Los Angeles in October 1988 and at the 16th international congress of chemotherapy, Jerusalem, in June 1989.

Other participants at the principal centres were I L Rosenberg and H B Devlin, North Tees General Hospital, Stockton; and E Hoare and P Sykes, Trafford General Hospital, Manchester.

Additional participating centres were Kingston General Hospital (R D Leach, G H Farrington, W J D Bradield, P E $M$ Jarrett, $P$ J Billings); Manchester Royal Infirmary ( $T$ V Taylor); Southmead Hospital, Bristol (D J Leaper, H J O White); Leigh Infirmary (J G Mosley, M C Holbrook); Arrowe Park Hospital, Wirral (M G Greaney, J S Elkington); Central Middlesex Hospital (N Menzies-Gow, J PayneJames); Middlesbrough General Hospital (W M Cooke, W A Corbett, D Clarke); St James's University Hospital, Leeds (T G Brennan, R C Kester, the late G Wilson); Prince Charles Hospital, Merthyr Tydfil (P A Braithwaite).

We thank Mrs C Finan, Sister S Walsh, Mrs J Davies, and Miss $J$ Hannington for valuable help with the trial documentation. We are also grateful to Mr P J Thomas for advising on the group sequential study design, Miss Kathryn Legge for performing the statistical analysis, and Miśs Helen Moore for word processing the manuscript.

1 Eykyn SJ, Jackson BT, Lockhart-Mummery HE, Phillips I. Prophylactic peroperative intravenous metronidazole in elective colorectal surgery. Lancet 1979;ii:761-4.

\title{
Stimulating reporting of adverse drug reactions by using a fee
}

Department of

Pharmacology and

Therapeutics, Trinity

College Medical School, St

James's Hospital, Dublin 8, Ireland

John Feely, MD, professor Siobhan Moriarty, BSC, pharmacist

Patricia O'Connor, MRCPI, lecturer/registrar

Correspondence to: Professor Feely.
2 Keighley MRB, Arabi Y, Alexander-Wiliams J, Youngs D, Burdon DW. Comparison between systemic and oral antimicrobial prophylaxis in colorectal surgery. Lance 1979;i:894-7.

3 Danziger L, Hassan E. Antimicrobial prophylaxis of gastrointestinal surgical procedures and treatment of intra-abdominal infections. Drug Intell Clin procedures and treatm
Pharm 1987;21:406-16.

4 Fry DE. Antibiotics in surgery. An overview. Am f Surg 1988;155(5A):11-5.

Haddock G, Hansell DT, McArdle CS. Survey of antibiotic prophylaxis in gastrointestinal surgery in Scotland -5 years on. 7 Hosp Infect 1988;11: 286-9.

6 Stubbs RS, Griggs NJ, Kelleher JP, Dickinson IK, Moat N, Rimmer DMD. Single dose mezlocillin versus three dose cefuroxime plus metronidazole for the prophylaxis of wound infection after large bowel surgery. I Hosp Infect 1987;9:285-90.

7 Mittermayer H, Gross C, Brucke P. Single dose cefuroxime/metronidazole versus metronidazole alone in elective colorectal surgery. Am Surg 1984;50: $418-23$

8 Cunliffe WJ, Carr N, Schofield PF. Prophylactic metronidazole with and without cefuroxime in elective colorectal surgery. A prospective randomised double-blind study. I $R$ Coll Surg Edinb 1985;30:123-5.

9 Colizza S, De Fazio S, Addari A, Grande R, Cucchiara G. Short-term prophylaxis with cefuroxime in colorectal surgery for cancer. $\mathcal{F}$ Surg Oncol 1987:35:266-8.

10 Jagelman DG, Fabian TC, Nichols RL, Stone HH, Wilson SE, Zellner SR. Single-dose cefotetan versus multiple-dose cefoxitin as prophylaxis in colorectal surgery. Am f Surg 1988;155(5A):71-6.

11 Burdon DW, Keighley MRB. Ceftriaxone and metronidazole as single-dose prophylaxis in colorectal surgery. $S$ Afr Med f 1987;71(suppl):15-8.

2 Shepherd A, Roberts A, Ambrose NS, Youngs DJ, Burdon DW, Keighley MRB. Ceftriaxone, a long acting cephalosporin, with metronidazole is a more effective combination than gentamicin with metronidazole as single dose prophylaxis in colorectal surgery. In: Ishigami J, ed. Proceedings of 14 th ICC Kyoto 1985. Tokyo: University of Tokyo Press, 1985:2425-6. (Recent Advances in Chemotherapy: antimicrobial section 3.)

13 Kingston RD, Kiff RS, Duthie JS, Walsh S, Spicer A, Jeacock J. A comparison of two prophylactic single-dose intravenous antibiotic regimes in the treatment of patients undergoing elective colorectal surgery in a in the treatment of patients undergoing elective colorectal
district general hospital. $₹ R$ Coll Surg Edinb 1989;34:208-11.

14 DiPiro JT, Welage LS, Levine BA, et al. Single-dose cefmetazole versus multiple dose cefoxitin for prophylaxis in abdominal surgery. I Antimicrob Chemother 1989;23 (suppl D):71-7.

15 Jones RN, Wojeski WV. Single-dose surgical prophylaxis using ticarcillin/ clavulanic acid (Timentin): a prospective, randomised comparison with cefotaxime. Diagn Microbiol Infect Dis 1987;7:219-23.

16 Rowe-Jones DC, Cole DS. Single dose mezlocillin versus three dose cefuroxime plus metronidazole for prophylaxis in large bowel surgery. 7 Hosp Infect 1988;12:131-2.

17 Sutton GLJ, Gartell PC, Karran SJ. An open controlled comparison of imipenem (MK-787/MK-791) vs metronidazole plus cefuroxime in the prevention of infectious morbidity complicating colorectral surgery. In Ishigami J, ed. Proceedings of 14th ICC Kvoto 1985. Tokyo: University of Tokyo Press, 1985:2474-5. (Recent Advances in Chemotherapy: antimicrobial Tokyo Press,

18 Diamond T, Mulholland CK, Hanna WA, Parks TG. A prospective randomised trial to compare triple dose mezlocillin with triple dose cefuroxime plus metronidazole as prophylaxis in colorectal surgery. cefuroxime plus metronid.
J Hosp Infect 1988:12:215-9.

19 Cann KJ, Watkins RM, George C, Payne-James J, Crawfurd E, Rogers TR. A Cann KJ, Watkins RM, George C, Payne-James J, Crawfurd E, Rogers TR. A
trial of mezlocillin versus cefuroxime with or without metronidazole for the prevention of wound sepsis after biliary and gastrointestinal surgery. $\mathcal{J}$ Hosp Infect 1988;12:207-14.

20 Whitehead J, Stratton I. Group sequential clinical trials with triangular continuation regions. Biometrics 1983;39:227-36.

21 Hastings RP, ed. SUGI supplemental library. In: SAS user's guide. Version 5 edition. Cary, NC: SAS Institute, 1986:269-93.

22 Donowitz GR, Mandell GL. Beta-lactam antibiotics. N Engl f Med 1988;318: $490-500$

23 Kingston RD, Duthie J. Serious postoperative bleeding associated with a single intravenous dose of cefuroxime and metronidazole. 7 Hosp Infect 1986;7:100-1.

24 Fuchs PC, Jones RN, Barry AL, Allen SD, Ayers LW, Pfaller M Desacetylcefotaxime - another broad spectrum cephalosporin? f Antimicrob Desacetylcefotaxime - ano
Chemother 1989;23:165-7.

(Accepted 19 October 1989)

\section{John Feely, Siobhan Moriarty, Patricia O’Connor}

Despite its limitations, spontaneous (yellow card) reporting of adverse drug reactions is the most effective surveillance system of drugs in clinical practice. Nevertheless, fewer than $10 \%$ of reactions are usually reported.' ' Because of the use of multiple and potent drugs one would expect reactions to occur more commonly in hospital than the reported $0.05 \% .^{3}$ To enhance the level of reporting we performed two studies: firstly a pharmacist collated reports, and, secondly, we offered a fee for each yellow card received.

\section{Patients, methods, and results}

In a six week survey of 136 beds a pharmacist examined patient records for adverse reactions and collected reports from nurses and prescribers who had been circulated with guidelines on reporting drug side effects. Thirty eight reactions were detected among 706 patients $(5 \cdot 4 \%)$, most $(21)$ from patient records; eight were reported by nurses but only three by prescribers (the rest came from a combination of sources).

We then offered IR£3 to junior doctors for each completed yellow card given to a designated registrar. Within six weeks 150 reports had been received (an incidence of $9 \cdot 7 \%$ ). These included two drug associated deaths (streptokinase anaphylaxis, pentamidine pancreatitis) and 27 serious or life threatening ${ }^{4}$ reactions -for example, bone marrow suppression, arrhythmias, gastrointestinal haemorrhage, warfarin interaction, pseudomembranous colitis, hepatotoxicity, and the 
Stevens-Johnson syndrome. An independent assessment of a random $25 \%$ sample confirmed the reports in over $90 \%$ of cases. A survey of the 40 reporting doctors identified "forgot/too busy" (4), unavailability of forms (18), and uncertainty about reporting system (6) as main constraints in reporting. The fee was an incentive for 32 . In the six weeks after withdrawal of the fee only 30 reports were received by the registrar.

\section{Comment}

Enhanced rates of reporting drug reactions will improve overall drug assessment, reduce bias, and speed earlier detection of serious toxicity with new drugs. Over the past six years our 800 bed hospital (15000 admissions yearly) has generated almost $0 \cdot 2 \%$ yellow cards per patient. Offering a fee increased the rate of reporting by almost 50 -fold, to $9 \cdot 7 \%$, whereas the pharmacist's survey detected a rate $(5 \cdot 4 \%)$ comparable to that in previous studies. ${ }^{1}$ Nevertheless, it identified a potential source of additional reportsnurses.

In the fee study we were unable to distinguish the value of reporting to an individual colleague, which we believe to be important, and the contribution of the fee, but the number of reports fell substantially after withdrawal of the fee. Two constraints-availability of yellow cards and lack of information on what to report - should be remediable. To counter the main constraint, "lack of time/forgetfulness," we can try only to ensure that reporting of reactions becomes an integral part of patient care.

Reporting fees are used in collecting other medical information such as notifiable diseases. We regard the use of a fee to stimulate reporting as an additional tool in drug assessment. Not only did use of the fee greatly enhance the number of reports, producing almost the equivalent to the previous six years' reports within six weeks; it also revealed many serious reactions, including those associated with newer treatments. In the normal course of events these reactions go unreported. We also introduced recently qualified doctors to the reporting system: $48 \%$ of the target group (in our case junior doctors) reported reactions over six weeks compared with a figure of $16 \%$ over 10 years for the current system. ${ }^{1}$ Further evaluation of the use of a reporting fee is warranted.

We thank the staff of St James's Hospital and the National Drugs Advisory Board for their cooperation.

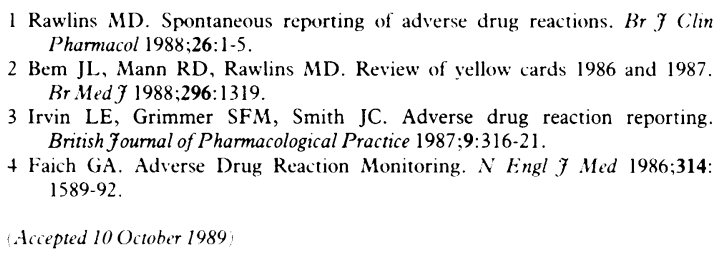

2 Bem JL, Mann RD, Rawlins MD. Review of vellow cards 1986 and 1987 Br.Med J 1988:296:1319.

3 Irvin LE, Grimmer SFM, Smith JC. Adverse drug reaction reporting. British fournal of Pharmacological Practice 1987;9:316-21.

+ Faich GA. Adverse Drug Reaction Monitoring. $N$ Fingl 7 Med 1986;314: 1589-92.

Accepted 10 October 1989

\section{Women's knowledge of their HIV antibody state: its effect on their decision whether to continue the pregnancy}

\author{
Frank D Johnstone, Ray P Brettle, Linda \\ R MacCallum, Jacqueline Mok, John \\ F Peutherer, Sheila Burns
}

\section{Department of Obstetrics and Gynaecology, Simpson Memorial Maternity Pavilion, Edinburgh EH3 9EF}

Frank D Johnstone, FRCOG, senior lecturer

\section{City Hospital Screening} Clinic, Edinburgh EH10 5SB

Ray P Brettle, MRCP, consultant

Linda R MacCallum, MB, research fellow

Jacqueline Mok, MRCP, consultant

\section{Department of}

Bacteriology, University of Edinburgh EH8 9AG

John F Peutherer, FRCPATH, senior lecturer

Regional Virus Laboratory, City Hospital, Edinburgh EH10 5SB

Sheila Burns, MRCPATH, senior registrar

Correspondence to: $\mathrm{Dr}$ Johnstone.

BrMed f 1990;300:23-4
Little is known about the attitudes of women infected with HIV towards pregnancy and whether they decide to continue a pregnancy or terminate it. It is often assumed that a high proportion of women who find that they are infected will terminate their pregnancy because of the risk to the baby, the possible risks to themselves, and their potentially limited life span. The main risk factors for HIV infection among women in Edinburgh are intravenous use of drugs and being the sexual partner of an infected drug user.' We studied the decisions made about pregnancy in all women with these risk factors.

\section{Patients, methods, and results}

A detailed community based record has been created for all pregnancies in women with the above risk factors whose HIV antibody state is known. ${ }^{12}$ Great care is taken to ensure both completeness and confidentiality of this record. We excluded pregnancies that spontaneously aborted, those confirmed before January 1986 , and those in women who did not know before 22 weeks or termination whether they were positive for HIV antibodies. We thus studied 163 pregnancies. Standard counselling was provided by several doctors and counsellors.

Induced abortion was common in both the women with and without HIV antibodies (table). Although a higher proportion of the women with HIV antibodies had induced abortions, the difference was not signif- cant $\left(\chi_{c}^{2}=1 \cdot 22, p>0 \cdot 20\right)$. Forty four women knew that they were positive for HIV antibodies when they became pregnant, and 21 of these had the pregnancy terminated. HIV infection was the main or only reason for termination in at least nine pregnancies: two of the women had AIDS and two had other illness related to HIV infection. Twenty five women were found to have HIV antibodies during pregnancy and knew the result before 22 weeks. Ten of these women had termination of pregnancy, but nine had previously requested abortion on other grounds and had been tested at that consultation. All 15 women who were found to have HIV antibodies when they attended the antenatal clinic continued their pregnancy. The 38 women who continued their pregnancy despite knowing that they had HIV antibodies in early pregnancy did so because they were currently in good health, desired to have one child, were against abortion, and knew women whose children were well and apparently not infected.

Outcome of pregnancy in women who were intravenous drug users or sexual partners of drug users positive for HIV antibodies ${ }^{\star}$

\begin{tabular}{|c|c|c|c|}
\hline & $\begin{array}{r}\text { Total No of } \\
\text { pregnancies }\end{array}$ & $\begin{array}{l}\text { No }(\%) \text { of } \\
\text { induced } \\
\text { abortions }\end{array}$ & $\begin{array}{c}95 \% \text { Confidence } \\
\text { interval }(\%)\end{array}$ \\
\hline \multicolumn{4}{|l|}{ Women positive for HIV } \\
\hline $\begin{array}{l}\text { antibodies } \\
\text { Tested before }\end{array}$ & $44^{69}$ & $\begin{array}{c}31(45) \\
21(48)\end{array}$ & 33 to 57 \\
\hline pregnancy & & $21(40)$ & 32603 \\
\hline $\begin{array}{l}\text { Tested during first } \\
\text { pregnancy }\end{array}$ & 25 & $10(40)$ & 21 to 61 \\
\hline $\begin{array}{l}\text { Women negative for HIV } \\
\text { antibodies }\end{array}$ & 94 & $33(35)$ & 26 to 46 \\
\hline All women & 163 & $64(39)$ & 31 to 47 \\
\hline
\end{tabular}

* Spontaneous abortions and women who did not know their antibody state before 22 weeks of pregnancy were excluded.

\section{Comment}

The combination of pregnancy and HIV infection can necessitate difficult decisions. The women we studied had a high rate of induced abortion, whether or not they were infected with HIV; the rate was nearly three times that in the city's overall population. Finding during pregnancy that they had HIV anti- 